\title{
Serum Urate and the Risk of Parkinson's Disease: Results From a Meta-Analysis
}

\author{
Chunhong Shen, Yi Guo, Wei Luo, Chen Lin, Meiping Ding
}

\begin{abstract}
Objective: Serum urate may exert protective effects against Parkinson's disease (PD) through its antioxidant capacities. In this article, we examine the hypothesis that high serum urate levels are associated with lower risk of PD. Methods: We searched NCBI (PubMed), ISI Web of Science and EMBASE for studies that reported the risk of PD associated with serum urate. Fixed or random effects meta-analysis was used to pool results across studies, and further analysis was used to assess the effects by gender. Results: Six studies met the inclusion criteria involving a total of 33185 participants. Overall, we found a $33 \%$ reduction in PD incidence among persons with high serum urate level (relative risk $[\mathrm{RR}]=0.67 ; 95 \%$ confidence interval [CI], 0.50-0.91). Subgroup analysis was performed with 20641 men and 12544 women included, indicating statistically significant protective effects of serum urate in men $(\mathrm{RR}=0.60 ; 95 \% \mathrm{CI}, 0.40-0.90)$ but not in women. A dose-response trend of serum urate to reduce PD risk was also observed involving 11795 participants $(\mathrm{RR}=0.77 ; 95 \% \mathrm{CI}, 0.68-0.88)$. Additionally, high serum urate levels seemed to slow the clinical decline of PD patients (RR=0.56; 95\% CI, 0.43-0.72). Conclusions: In light of these findings, our study confirms previous findings of a robust association between high serum urate level and PD risk, especially in men. It also suggests that long-term exposure to high serum urate may be linked to the delay of PD progression, however more well-designed investigations are needed.
\end{abstract}

RÉSUMÉ: Urate sérique et risque de maladie de Parkinson : résultats d'une méta-analyse. Objectif : L'urate sérique peut exercer des effets protecteurs contre la maladie de Parkinson (MP) de par ses propriétés antioxydantes. Dans cet article, nous examinons l'hypothèse selon laquelle un niveau élevé d'urate sérique est associé à un risque plus faible de MP. Méthode : Nous avons identifié les études qui faisaient état du risque de MP associé au taux d'urate sérique. La méta-analyse (modèle fixe ou aléatoire) a été utilisée pour combiner les résultats des études. Les données ont également été analysées selon le sexe des sujets. Résultats : Six études satisfaisaient aux critères d'inclusion, pour un total de 33185 sujets. Nous avons observé une diminution de $33 \%$ de l'incidence de la MP parmi les sujets qui avaient un taux d'urate sérique élevé (risque relatif [RR] = 0,67 ; intervalle de confiance [IC] à 95\%: 0,050 à 0,91). L'analyse de sous-groupes selon le sexe, soit 20641 hommes et 12544 femmes, a montré un effet protecteur significatif au point de vue statistique de l'urate sérique chez les hommes ( $R R=0,60 ; \mathrm{IC}$ à 95\%:0,40 à 0,90), mais non chez les femmes. Nous avons observé une tendance dose-réponse de l'urate sérique à diminuer le risque de la MP chez 11795 sujets ( $\mathrm{RR}=0,77 ; \mathrm{IC}$ à $95 \%$ : 0,68 à 0,88$)$. De plus, un taux élevé d'urate sérique semblait ralentir l'évolution clinique de la maladie chez les patients atteints de la MP (RR = 0,56; IC à 95\%: 0,43 à 0,72$)$. Conclusions : Ces observations confirment des observations antérieures d'un lien important entre un taux élevé d'urate sérique et le risque le la MP, surtout chez les hommes. De plus, une exposition à long terme à un taux élevé d'urate sérique pourrait être associée à une progression plus lente de la MP. Cependant, ces observations devront être confirmées par d'autres études bien conçues.

Can J Neurol Sci. 2013; 40: 73-79

Parkinson's disease (PD) is a common neurodegenerative movement disorder associated with substantial morbidity and mortality ${ }^{1}$, and the number of persons affected is expected to increase dramatically in coming years ${ }^{2}$. Although the exact cause of the selective dopaminergic cell death that underlies PD is still unknown, oxidative stress is regarded as a potential mechanism in the pathogenesis ${ }^{3}$ and evidence of oxidative damage, such as DNA and protein damage and lipid peroxidation, has been found at autopsy of PD brains ${ }^{4,5}$. Urate is thought to be a potent antioxidant that effectively scavenges oxygen radicals and reactive nitrogen ${ }^{6}$, and its potential protective effects on $\mathrm{PD}$ have been reported in prior studies. Some studies suggested that persons with high serum urate level have a markedly lower risk of developing $\mathrm{PD}^{7,8}$, while others showed no such benefits or negative effect ${ }^{9,10}$. Characterized by deposition of monosodium urate crystals in individuals with high serum urate level, gout is a common metabolic disorder. Alonso et $\mathrm{al}^{11}$ had indicated the history of gout may reduce the risk of developing PD.

Given these inconsistent possibilities, we attempted to establish what consensus, if any, could be reached from the different studies of the roles of urate in PD with meta-analytic techniques. Our major objective was to examine whether high serum urate level could lower the risk of PD. In addition, we also

\footnotetext{
From the Department of Neurology (CS, YG, WL, MD), Second Affiliated Hospital; School of Medicine (CL), Zhejiang University, Hangzhou, China.

Received May 22, 2012. Final Revisions Submitted August 20, 2012.

Correspondence to: Meiping Ding, Department of Neurology, Second Affiliated

Hospital, School of Medicine, Zhejiang University, No. 88, Jiefang Road, Hangzhou

310009, China. Email address: dingmeiping@tom.com.
} 
reviewed relevant articles to evaluate the association between serum urate and PD progression.

\section{MeTHODS}

\subsection{Search strategy}

Our systematic review was conducted according to the Metaanalysis of Observational Studies in Epidemiology (MOOSE) guidelines ${ }^{12}$. The authors including Chunhong Shen, Yi Guo and Chen Lin searched appropriate articles by systematic queries of NCBI (PubMed), ISI Web of Science and EMBASE databases on the 19th of March 2012. No language restriction was applied. Search strategy included terms for the medical subject heading (MeSH) terms "Parkinson's disease" and "urate" or "uric acid". We retrieved all the articles and searched reference lists to find other potentially relevant articles. Additionally, we were made aware of unpublished datasets such as clinical trials, but found no studies suitable for inclusion.

\subsection{Eligibility criteria}

All publications were carefully read and evaluated. Studies were included if they met the following criteria: 1) presented original data from epidemiologic studies; 2) a case-control or cohort design which evaluated the association between urate and PD; 3) diagnostic criteria for PD was clearly stated; 4) defined exposure as urate measured at laboratories, and ascertained exposure status before PD diagnosis; 5) reported odds ratios or relative risks or hazard ratios with $95 \%$ confidence intervals (CIs), and described adjustments for potential confoundings; 6) met at least six Newcastle-Ottawa Scale (NOS) criteria ${ }^{13}$, which is an eight item instrument, with up to nine possible points, and is intended to assess the quality of observational studies to be included in systematic reviews and meta-analysis.

\subsection{Data extraction}

The three authors mentioned above independently evaluated the eligibility of all retrieved studies from the databases and extracted the relevant data from each included study using a unified data form. The items included were as follows: study name, journal name, country and study design, study population, gender, age, follow-up year, outcome and exposure definition, effect estimates, variables adjusted for and so on. Finally, discrepancies were discussed and resolved by agreement.

\subsection{Data analysis}

Some studies included in our meta-analysis used the International System of Units (umoles/liter) to report levels of serum urate. We therefore converted $\mu \mathrm{mol} / \mathrm{liter}$ to the conventional units $(\mathrm{mg} / \mathrm{dl})$, using a conversion rate of 16.81 (1 $\mathrm{mg} / \mathrm{dl}=59.48 \mu \mathrm{mol} / \mathrm{l})$. Besides, most previous studies chose the categorical and continuous variable nearest to $6.8 \mathrm{mg} / \mathrm{dL}$ to define the hyperuricemic group which is the limit of urate solubility in serum ${ }^{14}$ but, so far, there is no universally accepted definition for hyperuricemia. For the present study, we used the term "high serum urate level" defined as the concentration nearest to $6.8 \mathrm{mg} / \mathrm{dl}$ instead of hyperuricemia.

We examined heterogeneity in results across studies using $\mathrm{I}^{2}$ statistics. The null hypothesis that the studies are homogeneous is rejected if the P-value for heterogeneity is less than 0.10 or I- square is greater than $50 \%$. When substantial heterogeneity was detected, the summary estimate based on the random effects model (DerSimonian and Laird method) was presented. Otherwise, the pooled estimate based on the fixed effects model (Mantel and Haenszel method) was presented. Subgroup analysis was carried out by gender (men vs women). In order to assess the influence of individual result on the pooled estimate, we conducted a sensitivity analysis by excluding each study one by one, and recalculating the combined estimates on the remaining studies.

We performed Egger's test and Begg's test to evaluate publication bias, p-value $<0.05$ for Egger's or Begg's tests was considered to be representative of significant statistical publication bias. All data analysis were performed using Stata/SE (11.1).

\section{RESULTS}

\subsection{Literature search}

Figure 1 shows a flow diagram of study selection. Of the 110 titles identified from the three databases, 83 articles were excluded after we had reviewed titles and abstracts, then 13 articles were excluded due to duplicated titles. Based on the full text of the remaining studies, we excluded four articles for the following reasons: no reporting relative risk (RR) and its $95 \%$ confidence interval (CI), cross-sectional survey ${ }^{15}$, only examining the relation between dietary urate index and PD risk ${ }^{7}$. We also ruled out two studies about urate and PD progression $^{16,17}$, and another two studies about gout and PD incidence ${ }^{11,18}$. Finally, we included six studies in the metaanalysis about the association between urate and PD risk ${ }^{8-10,19-21}$.

\subsection{Study characteristics}

Our search resulted in six studies on high serum urate level and PD incidence, involving a total of 33185 participants (Table 1). Although one cohort study measured urate concentration

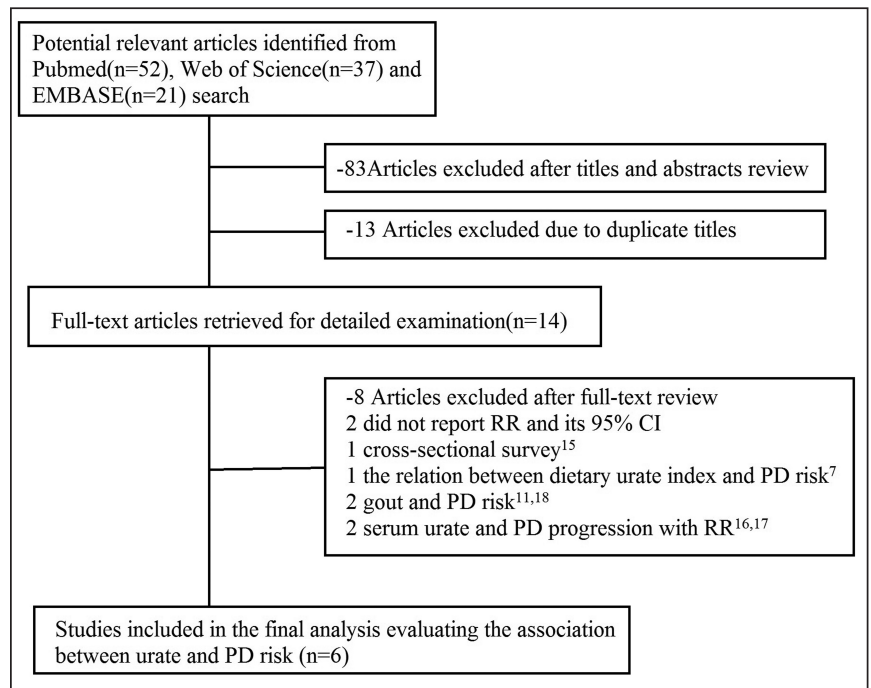

Figure 1: Flow diagram of study selection. 
Table 1: Characteristics of studies about the association between high serum urate levels and PD

\begin{tabular}{|c|c|c|c|c|c|c|c|}
\hline $\begin{array}{l}\text { Author, } \\
\text { year, } \\
\text { country }\end{array}$ & $\begin{array}{l}\text { No. case } \\
\text { /total } \\
\text { /control }\end{array}$ & $\begin{array}{l}\text { Gender } \\
\text { Age }^{*}\end{array}$ & $\begin{array}{l}\text { Follow-up } \\
\text { years }\end{array}$ & $\begin{array}{l}\text { Hyperuri } \\
\text {-cemia } \\
\mathrm{mg} / \mathrm{dl}\end{array}$ & $\begin{array}{l}\text { No. } \\
\text { PD }\end{array}$ & $\begin{array}{l}\text { Outcome (PD) } \\
\text { Definition }\end{array}$ & $\begin{array}{l}\text { Potential confounders } \\
\text { Considered }\end{array}$ \\
\hline \multicolumn{8}{|c|}{ Cohort study for urate and PD incidence } \\
\hline $\begin{array}{l}\text { Davis, } 1996 \\
\mathrm{US}^{9}\end{array}$ & $92 / 6851$ & $\begin{array}{l}M \\
45-68\end{array}$ & 24 & $7.2^{\mathrm{a}}$ & 76 & by neurologists or neurosurgeons & age, smoking \\
\hline $\begin{array}{l}\text { De Lau, } 2005 \\
\text { Netherlands }^{8}\end{array}$ & $68 / 4695$ & C & 9.4 & $6.29^{\mathrm{a}}$ & 68 & $\begin{array}{l}\text { screened positive received a structural } \\
\text { diagnostic workup }\end{array}$ & $\begin{array}{l}\text { age, sex, smoking, alcohol, dairy products, } \\
\text { BMI }\end{array}$ \\
\hline $\begin{array}{l}\text { Chen, } 2009 \\
\text { US }^{19}\end{array}$ & $95 / 15036$ & $\begin{array}{l}\mathrm{M} / \mathrm{W} \\
45-64\end{array}$ & 17 & $7.06^{\mathrm{a}}$ & 95 & $\begin{array}{l}\text { ICD diagnosis or self-reported PD with } \\
\text { confirmation by movement disorder } \\
\text { specialist }\end{array}$ & $\begin{array}{l}\text { age, sex, race, smoking, caffeine, BMI, } \\
\text { alcohol, serum creatinine }\end{array}$ \\
\hline $\begin{array}{l}\text { Jain, } 2011 \\
\mathrm{US}^{20}\end{array}$ & $154 / 5749$ & $\begin{array}{l}\mathrm{M} / \mathrm{W} \\
67-78\end{array}$ & 14 & $8.41^{\mathrm{b}}$ & 154 & $\begin{array}{l}\text { self-report, medication and hospitalization } \\
\text { records }\end{array}$ & $\begin{array}{l}\text { age, smoking, race, BMI, alcohol, creatinine, } \\
\text { diabetes, hypertension, uricosurics,EKG }\end{array}$ \\
\hline \multicolumn{8}{|c|}{ Nested case-control study for urate and PD incidence } \\
\hline $\begin{array}{l}\text { O'Reilly, } 2010 \\
\text { US }^{21}\end{array}$ & $101 / 504$ & $\begin{array}{l}\text { W } \\
30-55\end{array}$ & 14 & $5.8^{\mathrm{a}}$ & & $\begin{array}{l}\text { self-reported PD with confirmation by } \\
\text { treating physicians and movement } \\
\text { disorder specialist }\end{array}$ & age, smoking, and caffeine \\
\hline $\begin{array}{l}\text { Weisskopf, } 2007 \\
\text { US }^{10}\end{array}$ & $84 / 165$ & $\begin{array}{l}M \\
40-75\end{array}$ & 9 & $6.9^{\mathrm{a}}$ & & $\begin{array}{l}\text { diagnostic validations for self-reported PD } \\
\text { by treating neurologists or internists }\end{array}$ & age, smoking, caffeine intake \\
\hline \multicolumn{8}{|c|}{ Cohort study for urate and PD progression } \\
\hline $\begin{array}{l}\text { Schwarzschild, } 2008 \\
\mathrm{US}^{16}\end{array}$ & 804 & $\begin{array}{l}\mathrm{M} / \mathrm{W} \\
57-61\end{array}$ & 1.8 & $6.7^{\mathrm{c}}$ & 493 & $\begin{array}{l}\text { disability sufficient to require levodopa } \\
\text { therapy }\end{array}$ & age and sex \\
\hline $\begin{array}{l}\text { Ascherio, } 2009 \\
\text { US \& Canada }^{17}\end{array}$ & 800 & $\mathrm{M} / \mathrm{W}$ & 2 & $6.21^{\mathrm{c}}$ & 369 & $\begin{array}{l}\text { disability sufficient to require levodopa } \\
\text { therapy }\end{array}$ & $\begin{array}{l}\text { age, sex, and treatment group (deprenyl or } \\
\text { placebo) }\end{array}$ \\
\hline \multicolumn{8}{|c|}{ Cohort and nested case-control study for gout and PD incidence } \\
\hline $\begin{array}{l}\text { De Vera, } 2008 \\
\text { British } \\
\text { Columbia }^{18}\end{array}$ & $\begin{array}{l}1182 / \\
67457\end{array}$ & $\begin{array}{l}\mathrm{M} / \mathrm{W} \\
74.1\end{array}$ & 8 & - & $\begin{array}{l}118 \\
2\end{array}$ & the ICD-9 code & $\begin{array}{l}\text { age, sex, hypertension, diabetes, } \\
\text { hyperlipidemia, COPD, Charlson } \\
\text { comorbidity score, diuretic use and NSAID }\end{array}$ \\
\hline $\begin{array}{l}\text { Alonso, } 2007 \\
\text { Britian \& } \\
\text { Canada }^{11}\end{array}$ & $\begin{array}{l}1052 / \\
6634\end{array}$ & $\begin{array}{l}\mathrm{M} / \mathrm{W} \\
69-70\end{array}$ & 6 & - & - & $\begin{array}{l}\text { computer-recorded PD with confirmation } \\
\text { of the related paper records }\end{array}$ & age, sex, practice and smoking \\
\hline
\end{tabular}

NSAID=nonsteroidal antiinflammatory drugs, $\mathrm{BMI}=$ body mass index, $\mathrm{EKG}=$ electrocardiogram, $\mathrm{COPD}=$ chronic obstructive pulmonary disease, $\mathrm{M}=$ men, $\mathrm{W}=$ woman, $\mathrm{C}=$ combined. *Age range or median age; a Highest quartile to lowest quartile of serum urate level; $\mathrm{b}$ Above to below the cut point of serum urate level; c Highest quintile to lowest quartile of serum urate level

twice, the RRs were largely based on the same incident PD cases, so we just extracted one $\mathrm{RR}^{9}$. Four of six studies were cohort studies $^{8,9,19,20}$ while two were nested case-control studies ${ }^{10,21}$. Two studies presented results for both men and women ${ }^{19,20}$. Two in men only $y^{9,21}$, one study in women only ${ }^{10}$ and one combined ${ }^{8}$, results for men and women, which included 20641 men and 12 544 women. Moreover, three studies involving 11795 participants reported results when urate was modeled as a continuous variable ranged from 4.5 to $6.9 \mathrm{umol} / 18,9,21$, and four studies gave results after excluding cases identified during the early years of follow-up ( $\geq 4$ years) $)^{9,10,19,21}$. Additionally, we retrieved two studies with RR about urate and PD progression and two studies about gout and PD risk were also described (Table 1).

\subsection{Serum urate and PD incidence}

As is shown in Figure 2, the pooled estimate for the six studies that reported the association between high serum urate and PD on the fixed effects model was 0.67 (95\% CI, 0.50-0.91; p_heterogeneity $\left.=0.098, \mathrm{I}^{2}=42.1 \%\right)$. When evaluated on random effects model, the RR was 0.65 (95\% CI, 0.43-0.97). Further, there was no indication of a publication bias either from the result of Egger's test $(\mathrm{P}=0.390)$ or Begg's test $(\mathrm{P}=0.536)$, and the shape of the funnel plot seemed symmetrical (Figure 3 ).

Table 2 shows the effects of high serum urate on PD risk in subgroup meta-analysis. Compared with overall analysis, the association was strengthened among men based on four studies $(\mathrm{RR}=0.60 ; 95 \% \mathrm{CI}, 0.40-0.90)$ whereas it appeared as a weak 
non-significant result among women ( $R R=0.99 ; 95 \%$ CI, 0.591.67). When analysis was restricted to studies that excluded PD cases identified during early years of follow-up, the result was similar with the overall result ( $R R=0.64 ; 95 \% \mathrm{CI}, 0.49-0.83)$. In additional analysis, a dose-response trend was observed relating high serum urate levels to PD risk; this trend was statistically significant $\left(\mathrm{RR}=0.77 ; 95 \% \mathrm{CI}, 0.68-0.88\right.$; $\mathrm{p} \_$heterogeneity= $0.809)$.

In sensitivity analysis, we recalculated the combined results by excluding one study per iteration. The study-specific RRs ranged from a low of 0.57 (95\% CI, 0.41-0.79) via omission of the study by O'Reilly et al, to a high of 0.76 (95\% CI, 0.55-1.05) via omission of the study by Chen et al respectively, thus were similar without great fluctuations (data not shown).

\subsection{Serum urate and PD progression}

Table 2 shows high serum urate seems to slow the progression of reaching the endpoint decline of PD identified as time to disability requiring dopaminergic therapy $(R R=0.56$; 95\% CI, 0.43-0.72; p_heterogeneity $=0.38$ ). The RR among men on the random effects was $0.50(95 \% \mathrm{CI}, 0.30-0.85)$ while it is 0.70 among women (95\% CI, 0.41-1.21). Besides the studies with RR above, there were several articles investigating serum urate concentration stratified by Hoehn-Yahr stages, disease duration, age of onset. Two research studies ${ }^{22,23}$ showed serum urate was inversely correlated with both PD H-Y stage and disease duration $(\mathrm{P}<0.01)$. The results stratified by sex were also statistically significant. However, Jesus ${ }^{24}$ compared urate concentration between PD and control groups in southern Spain, noting serum urate was lower in patients with PD in severe stages than in those in moderate stage for combined sexes and for men only, but not for women only, which is consistent with our meta-analysis result.

\subsection{Gout and PD incidence}

The pooled estimate of RR based on two studies that reported the association between gout and PD was 0.70 (95\% CI, 0.60-
0.82 ), and the RR among men was 0.69 (95\% CI, 0.58-0.82) whereas gout was not associated with PD among women $(\mathrm{RR}=0.83 ; 95 \% \mathrm{CI}, 0.46-1.48)$ when findings were summarized with a random effects model as is shown in Table 2.

\section{Discussion}

Our meta-analysis synthesized all available, compatible data from cohort or case-control studies reporting on the association of serum urate level with the risk of PD. Findings from the present study, including four prospective cohort studies and two nested case-control studies, have confirmed that high serum urate is associated with a $33 \%$ reduction on the risk of PD, consistent with a dose-response relation $(\mathrm{R} R=0.77)$. We also evaluated studies which have excluded cases diagnosed as PD during the early years, and the magnitude of risk reduction reported was similar with that in the overall analysis, which may strongly support the inverse effect between high serum urate and PD risk. Consistent with the above results, the inverse association between history of gout and risk of PD also existed. The potential mechanisms behind the observed protective association include the antioxidant properties of urate.

When stratified by gender, the protective effect of high serum urate level on PD was only present in men but not in women, which further weakened the overall protective effect. Interestingly, a gender difference has also been reported for the effect of caffeine on PD risk, and the inverse effect was attenuated among users of postmenopausal hormones ${ }^{25}$. We speculate that the stronger association in men could be due to a biological effect of gender on neurodegenerative disorders, as estrogen may increase mitochondrial respiration efficiency resulting in a lower oxidative load, or play an antioxidant role ${ }^{26}$. Moreover, studies showed there was a substantially lower average urate concentration for women than men, suggesting a paucity of women in the uppermost quintiles, which may contribute to the lack of a clear link between urate and PD. The nested case-control studies we included are prospective, whose cases and controls are actually taken from a cohort study.

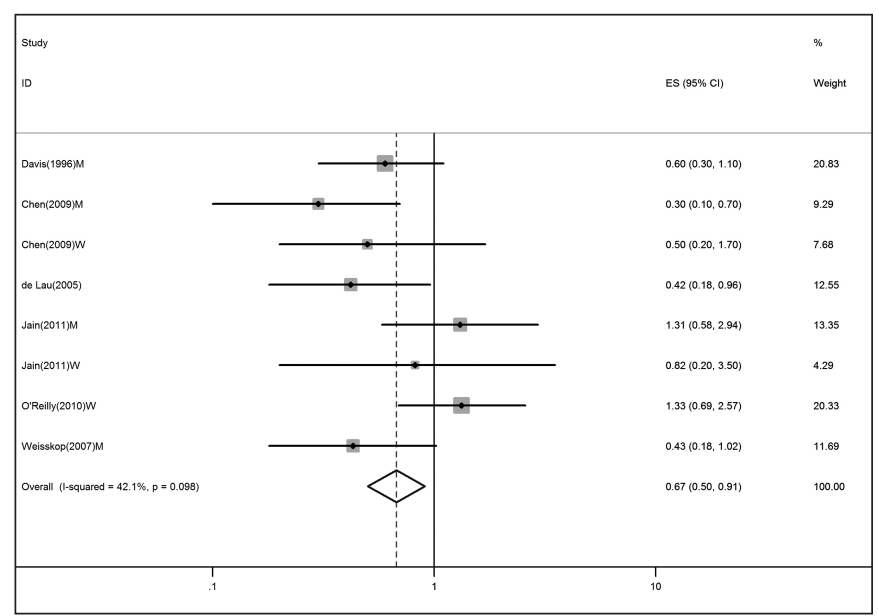

Figure 2: Relative risks (95\% confidence intervals) from studies about the association between high serum urate level and PD incidence.

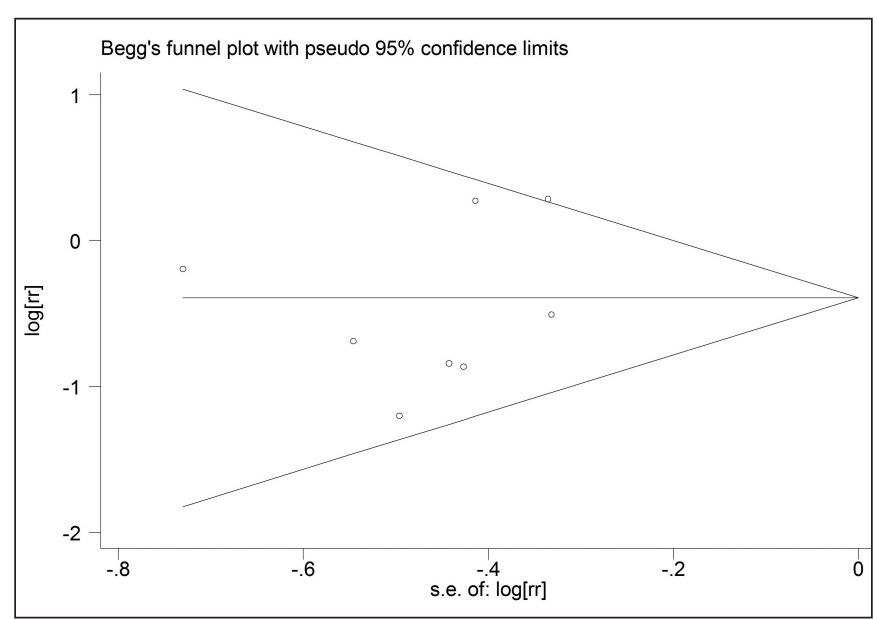

Figure 3: Publication bias from studies about the association between high serum urate level and PD incidence. 
Table 2: Summary risk estimates of the association between high serum urate level or gout and PD

\begin{tabular}{|c|c|c|c|c|c|}
\hline \multirow[b]{3}{*}{ All studies (urate and PD incidence) } & \multirow{3}{*}{$\begin{array}{c}\text { No. of Studies (data) } \\
6(8)\end{array}$} & \multirow[t]{2}{*}{ No. } & \multirow[t]{2}{*}{$\mathrm{RR}(95 \% \mathrm{CI})$} & \multicolumn{2}{|c|}{ Heterogeneity test } \\
\hline & & & & $\mathrm{P}$ & I-square $(\%)$ \\
\hline & & 33185 & $0.68(0.50-0.91)$ & 0.098 & 42.1 \\
\hline Men & 4 & 20641 & $0.60(0.40-0.90)$ & 0.108 & 50.6 \\
\hline Women & 3 & 12544 & $0.99(0.59-1.67)$ & 0.300 & 16.9 \\
\hline Excluding cases identified during early years & 4 & - & $0.64(0.49-0.83)$ & 0.233 & 29.9 \\
\hline Dose-respond trend & 3 & 11795 & $0.77(0.68-0.88)$ & 0.809 & 0.0 \\
\hline All studies (urate and PD progression) & 2 & 1578 & $0.56(0.43-0.72)$ & 0.378 & 0.0 \\
\hline Men & 2 & 1027 & $0.50(0.30,0.85)$ & 0.103 & 62.4 \\
\hline Women & 2 & 551 & $0.70(0.41-1.21)$ & 0.630 & 0.0 \\
\hline All studies (gout and PD incidence) & 2 & 75143 & $0.70(0.60-0.82)$ & 0.944 & 0.0 \\
\hline Men & 2 & 49365 & $0.69(0.58-0.82)$ & 0.469 & 0.0 \\
\hline Women & 2 & 25878 & $0.83(0.46-1.48)$ & 0.154 & 50.9 \\
\hline
\end{tabular}

Therefore it does not make sense to isolate these two studies based on their study design. Even if we do the nested casecontrol analysis, one study is men and one is women, and the $\mathrm{RR}=0.79$ is a weighted average of the $\mathrm{RR}$ in men 0.60 and $\mathrm{RR}$ for women 0.99 , which we think can be explained by the lack of effect in women as indicated above.

We also found that the rate of PD progression to the clinical endpoint declined with increasing levels of baseline serum urate, especially in men, but the number of studies included was quite limited, due to the lack of relevant articles with same parameters to evaluate the disease progression. One of the studies ${ }^{16}$ retrieved had secondary endpoints that included changes in the Unified PD Rating Scale (UPDRS) and $\beta$-CIT SPECT imaging of ligand binding to striatal dopamine transporter, which indicated that the rate of change in UPDRS and the percent loss in striatal [123I] $\beta$ CIT uptake improved with increasing serum urate. A recent serological study ${ }^{27}$ also indicated that serum urate level was inversely related to PD duration and Yahr stage which allocates stages from 0 to 5 to assess the relative level of disability. Andreadou et $\mathrm{al}^{28}$ observed strong and significant inverse correlations of serum urate with disease duration and daily levodopa dosage. To summarize, studies we retrieved confirmed that high serum urate was involved in the delay of PD progression. However, some studies showed the linkage was significant in men but not for woman, others did not. This requires further investigation and more well-designed studies.

The mechanism of underlying positive associations between high serum urate and PD are not yet very clear. Urate, the anionic form of uric acid (2,6,8-trioxy-purine), predominates at neutral $\mathrm{pH}$, and is present both intracellularly and in all body fluids. In humans, urate is synthesized by the xanthine oxidoreductase enzyme, which successively oxidizes hypoxanthine to xanthine and then to urate as the main end product of purine metabolism. Primarily through its actions as a powerful scavenger of peroxynitrite and hydroxyl radicals to reduce oxidative stress, urate may exert a key role on the prevalence and progression of PD. In a mouse model of PD, treatment with urate suppressed oxidative stress and prevented death of dopaminergic cells caused by administration of homocysteine or iron ${ }^{29}$. Possible mechanisms for the neuroprotective role include suppression of oxyradical accumulation and preservation of mitochondrial function, peroxynitrite scavenger ${ }^{30}$, ascorbate stabilizer $^{31}$, inhibition of the cytotoxic activity of lactoperoxidase ${ }^{32}$, and protection from dopamine-induced apoptosis ${ }^{33}$. Urate has also been demonstrated to reduce oxidation of dopamine in caudate and substantia nigra and primary midbrain culture of PD patients ${ }^{34,35}$. Although the cerebrospinal fluid urate concentration is only about seven percent that of serum, urate is still important in the brain because of its distinct antioxidant effects or its ability to stabilize ascorbate ${ }^{36}$. A recent study has provided anther possibility that cerebrospinal fluid urate could prevent the increase in permeability of the blood-brain barrier observed in inflammatory diseases of the central nervous system, such as Borna disease virus encephalitis ${ }^{37,38}$. Studies have already shown high cerebrospinal fluid urate concentrations at baseline are associated with slower rates of clinical decline of PD patients ${ }^{17}$. Also, urate's protective effect has been linked to its ability to complex with metal ions such as iron and copper, which promote formation of highly reactive hydroxyl free radicals ${ }^{39}$, thus reducing their oxidizing potential ${ }^{40,41}$.

Our study had several limitations. First, as our results were based on observational studies, the results of the present and previous investigations can not establish whether serum urate and a low rate of PD share an unknown common cause, or 
whether high level of urate is causally related to the rate of PD including the possiblity that the protective role is the effect of a urate precursor rather than urate itself. Second, our analysis brought into both studies in which RR was evaluated with the highest quartile of uricemia versus the lowest and above-average versus below-average urate level, which may have some unknown effects on our study, however seem to be nonsignificant. Third, all the studies attempted to control for potential confounders, but the degree to which this was done varied. Given that we still have much to learn about PD, residual confounding may have played a part in the study's findings. Finally, considering the strict inclusion criteria of meta-analysis which includes cohort or case-control studies and removes crosssectional studies, our article contains a limited number of studies. We cannot exclude the possibility of publication bias, though there is little evidence of publication bias as shown by Egger's and Begg's test.

A potentially protective and therapeutic effect of elevating serum urate concentration warrants consideration. Urate levels can be elevated by dietary means or pharmacological means such as urate precursor inosine, which is being investigated as a therapy for multiple sclerosis ${ }^{42}$. Previous epidemiologic studies have frequently noted serum urate may increase the risk of hypertension, coronary heart disease, stroke and metabolic diseases ${ }^{43-45}$, which means the potential benefit of elevating urate concentration in individuals with PD, has to be weighed against possible adverse effects. To conclude, our study confirms a strong association between high serum urate level and PD in men, however the available data are insufficient to support a therapeutic potential of urate on PD.

\section{ACKNOWLEDGMENT}

This project was supported by grants from the National Natural Science Foundation of China $(81171227,81000556)$.

\section{REFERENCES}

1. Driver JA, Kurth T, Buring JE, Gaziano JM, Logroscino G. Parkinson disease and risk of mortality: a prospective comorbidity-matched cohort study. Neurology. 2008;70(pt 2): 1423-30.

2. Dorsey ER, Constantinescu R, Thompson JP, et al. Projected number of people with Parkinson disease in the most populous nations, 2005 through 2030. Neurology. 2007;68:384-6.

3. Schlesinger I, Schlesinger N. Uric acid in Parkinson's disease. Mov Disord. 2008;23:1653-7.

4. Jenner P. Oxidative stress and Parkinson's disease. Handb Clin Neurol. 2007;83:507-20.

5. Lotharius J, Brundin P. Pathogenesis of Parkinson's disease: dopamine, vesicles and alpha-synuclein. Nat Rev Neurosci. 2002;3(12):932-42.

6. Ames BN, Cathcart R, Schwiers E, Hochstein P. Uric acid provides an antioxidant defense in humans against oxidant- and radicalcaused aging and cancer: a hypothesis. Proc Natl Acad Sci. 1981;78:6858-62.

7. Gao X, Chen H, Choi HK, Curhan G, Schwarzschild MA, Ascherio A. Diet, urate, and Parkinson's disease risk in men. Am J Epidemiol. 2008;167(7):831-8.

8. De Lau LM, Koudstaal PJ, Hofman A, Breteler MMB. Serum uric acid levels and the risk of Parkinson disease. Ann Neurol. 2005;58(5):797-800.

9. Davis JW, Grandinetti A, Waslien CI, Ross GW, White LR, Morens DM. Observations on serum uric acid levels and the risk of idiopathic Parkinson's disease. Am J Epidemiol. 1996;144(5): 480-4.
10. O'Reilly ÉJ, Gao X, Weisskopf MG, et al. Plasma urate and Parkinson's disease in women. Am J Epidemiol. 2010;172(6): 666-70.

11. Alonso A, Rodríguez LAG, Logroscino G, Hernán MA. Gout and risk of Parkinson disease: a prospective study. Neurology. 2007; 69(17):1696-700.

12. Stroup DF, Berlin JA, Morton SC, et al. Meta-analysis of observational studies in epidemiology: a proposal for reporting. meta-analysis of observational studies in epidemiology (MOOSE) group. JAMA. 2000;283:2008-12.

13. Wells G, Shea B, O'Connell D, et al. The Newcastle-Ottawa Scale (NOS) for assessing the quality of nonrandomized studies in meta-analyses. Ottawa Health Research Institute.

14. Wilcox WR, Khalaf A, Weinberger A, et al. Solubility of uric acid and monosodium urate. Med Biol Eng. 1972;10(4):522-31.

15. Winquist A, Steenland K, Shankar A. High serum uric acid associated with decreased Parkinson's disease prevalence in a large community-based survey. Mov Disord. 2010;25:932-6.

16. Schwarzschild MA, Schwid SR, Marek K, et al. Serum urate as a predictor of clinical and radiographic progression in Parkinson disease. Arch Neurol. 2008;65(6):716-23.

17. Ascherio A, LeWitt PA, Xu K, et al. Urate as a predictor of the rate of clinical decline in Parkinson disease. Arch Neurol. 2009;66 (12):1460-8

18. De Vera M, Rahman MM, Rankin J, Kopec J, Gao X, Choi H. Gout and the risk of Parkinson's disease: a cohort study. Arthritis Rheum. 2008;59(11):1549-54.

19. Chen H, Mosley TH, Alonso A, Huang X. Plasma urate and Parkinson's disease in the Atherosclerosis Risk in Communities (ARIC) study. Am J Epidemiol. 2009;169(9):1064-9.

20. Jain S, Ton TG, Boudreau RM, et al. The risk of Parkinson disease associated with urate in a community-based cohort of older adults. Neuroepidemiology. 2011;36(4):223-9.

21. Weisskopf MG, O'reilly ÉJ, Chen H, Schwarzschild MA, Ascherio A. Plasma urate and risk of Parkinson's disease. Am J Epidemiol. 2007;166(5):561-7.

22. Zhang HN, Guo JF, He D, et al. Lower serum UA levels in Parkinson's disease patients in the Chinese population. Neurosci Lett. 2012;514:152-5

23. Sun CC, Luo FF, Wei L, et al. Association of serum uric acid levels with the progression of Parkinson's disease in Chinese patients. Chinese Med J-Peking. 2012;125(4):583-7

24. Jesús S, Pérez I, Cáceres-Redondo MT, et al. Low serum uric acid concentration in Parkinson's disease in southern Spain. Eur J Neurol. 2012 May 12. doi: 10.1111/j.1468-1331.2012.03745.x. [Epub ahead of print]

25. Ascherio A, Weisskopf MG, O'Reilly ÉJ, et al. Coffee consumption, gender, and Parkinson's disease mortality in the Cancer Prevention Study II cohort: the modifying effects of estrogen. Am J Epidemiol. 2004;160(10):977-84.

26. Nilsen J, Brinton RD. Mitochondria as therapeutic targets of estrogen action in the central nervous system. Curr Drug Targets Neurol Disord. 2004;3:297-313.

27. Ikeda K, Nakamura Y, Kiyozuka T, et al. Serological profiles of urate, paraoxonase-1, ferritin and lipid in Parkinson's disease: changes linked to disease progression. Neurodegener Dis. 2011; $8(4): 252-8$

28. Andreadou E, Nikolaou C, Gournaras F, et al. Serum uric acid levels in patients with Parkinson's disease: their relationship to treatment and disease duration. Clin Neurol Neurosur. 2009;111 (9):724-8

29. Duan W, Ladenheim B, Cutler RG, Kruman II, Cadet JL, Mattson MP. Dietary folate deficiency and elevated homocysteine levels endanger dopaminergic neurons in models of Parkinson's disease. J. Neurochem. 2002;80(1):101-10.

30. Whiteman M, Ketsawatsakul U, Halliwell B. A reassessment of the peroxynitrite scavenging activity of uric acid. Ann NY Acad Sci. 2002;962:242-59.

31. Sies H. Oxidative stress:oxidants and antioxidants. Exp Physiol. 1997;82:291-5.

32. Everse J, Coates PW. The cytotoxic activity of lactoperoxidase: enhancement and inhibition by neuroactive compounds. Free Radic Biol Med. 2004; 37:839-49. 
33. Jones DC, Gunasekar PG, Borowitz JL, Isom GE. Dopamineinduced apoptosis is mediated by oxidative stress and is enhanced by cyanide in differentiated PC12 cells. J Neurochem. 2000;74:2296-304.

34. Church WH, Ward VL. Uric acid is reduced in the substantia nigra in Parkinson's disease: effect on dopamine oxidation. Brain Res Bull. 1994;33(4):419-25.

35. Guerreiro S, Ponceau A, Toulorge D, et al. Protection of midbrain dopaminergic neurons by the end-product of purine metabolism uric acid: potentiation by low-level depolarization. J Neurochem. 2009;109(4):1118-28.

36. Niklasson F, Agren H. Brain energy metabolism and bloodbrain barrier permeability in depressive patients: analyses of creatine, creatinine, urate, and albumin in CSF and blood. Biol Psychiatry. 1984;19:1183-206.

37. Kortekaas R, Leenders KL, Van Oostrom JC, et al. Bloodbrainbarrier dysfunction in parkinsonian midbrain in vivo. Ann Neurol. 2005;57:176-9.

38. Hooper DC, Kean RB, Scott GS, et al. The central nervous system inflammatory response to neurotropic virus infection is peroxynitrite dependent. J Immunol. 2001;167: 3470-7.

39. Kehrer JP. The Haber-Weiss reaction and mechanisms of toxicity. Toxicology. 2000;149(1):43-50.
40. Miura T, Muraoka S, Ogiso T. Inhibitory effect of urate on oxidative damage induced by adriamycin- $\mathrm{Fe} 3+$ in the presence of $\mathrm{H}_{2} \mathrm{O}_{2}$. Res Commun Chem Pathol Pharmacol. 1993;79(1): 75-85.

41. Einsele H, Clemens MR, Wegner U, Waller HD. Effect of free radical scavengers and metal ion chelators on hydrogen peroxide and phenylhydrazine induced red blood cell lipid peroxidation. Free Radical Res. 1987;3(1-5):257-63.

42. Spitsin S, Hooper DC, Leist T, Streletz LJ, Mikheeva T, Koprowskiet H. Inactivation of peroxynitrite in multiple sclerosis patients after oral administration of inosine may suggest possible approaches to therapy of the disease. Mult Scler. 2001;7(5):313-9.

43. Wheeler JG, Juzwishin KD, Eiriksdottir G, Gudnason V, Danesh J. Serum uric acid and coronary heart disease in 9458 incident cases and 155084 controls: prospective study and meta-analysis. PLoS Med. 2005;2(3):e76.

44. Grayson PC, Kim SY, Valley ML, Choi HK. Hyperuricemia and incident hypertension: a systematic review and meta-analysis. Arthritis Care Res. 2011;63(1):102-10.

45. Kim SY, Guevara JP, Kim KM, Choi HK, Heitjan DF, Albert DA. Hyperuricemia and risk of stroke: A systematic review and metaanalysis. Arthrit Care Res. 2009;61(7):885-92. 